\title{
$\mathrm{CeO}_{2}$ 助 $\mathrm{Ni} / \mathrm{MgO}$ 催化剂用于化学气相沉积法制备多壁碳纳米管
}

\author{
杨 文, 储 伟, 江成发 ${ }^{*}$, 文 婕, 孙文晶 \\ 四川大学化工学院, 四川成都 610065
}

\begin{abstract}
摘要：以柠檬酸燃烧法制备的 $\mathrm{Ni} / \mathrm{MgO}, \mathrm{Ni} / \mathrm{CeO}_{2}-\mathrm{MgO}$ 和 $\mathrm{Ni} / \mathrm{CeO}_{2}$ 为催化剂, $\mathrm{CH}_{4}$ 为碳源, 采用化学气相沉积法制备多壁碳纳米管 (MWCNTs), 通过 $\mathrm{N}_{2}$ 吸附、 $\mathrm{X}$ 射线衍射、 $\mathrm{H}_{2}$ 程序升温还原和 $\mathrm{X}$ 射线光电子能谱对催化剂进行表征, 并运用热重和透射电镜表征 了碳纳米管的质量和形貌. 结果表明, $\mathrm{CeO}_{2}$ 的加入可有效地降低还原温度和增加易还原 $\mathrm{Ni}$ 物种的含量, 并使电子发生转移, 还 原后的 $\mathrm{Ni} / \mathrm{CeO}_{2}-\mathrm{MgO}$ 催化剂中, $\mathrm{Ni}$ 晶粒尺寸较小. 这表明 $\mathrm{CeO}_{2}$ 的加入使得 $\mathrm{Ni}$ 物种的化学环境发生改变, 导致它和载体间的相 互作用减弱, 从而促进 $\mathrm{Ni}$ 物种的还原, 且还原后, 高度分散在 $\mathrm{CeO}_{2}-\mathrm{MgO}$ 载体上, 从而催化剂的催化活性增加. 相比 $\mathrm{Ni} / \mathrm{MgO}$ 催化 剂, $\mathrm{Ni} / \mathrm{CeO}_{2}-\mathrm{MgO}$ 为催化剂上生长的 $\mathrm{CNTs}$ 质量更高. 另外, 由 $\mathrm{CeO}_{2}$ 助 $\mathrm{Ni} / \mathrm{MgO}$ 催化剂制备出基本没有无定形碳、结晶度好的碳 纳米管.
\end{abstract}

关键词：镍; 氧化镁; 二氧化铈; 化学气相沉积法; 碳纳米管; 甲烷裂解

中图分类号：0643 文献标识码：A

收稿日期: 2011-03-28. 接受日期: 2011-04-25.

*通讯联系人. 电话: (028)85403836; 传真: (028)85461108; 电子信箱: jiangcf1@yahoo.com

基金来源：中央高校基本科研业务费 (2010SCU22010); 国家重点基础研究发展计划 (973 计划, 2011CB201202).

本文的英文电子版(国际版)由Elsevier出版社在ScienceDirect上出版(http://www.sciencedirect.com/science/journal/18722067).

\section{Cerium Oxide Promoted Ni/MgO Catalyst for the Synthesis of Multi-walled Carbon Nanotubes}

\author{
YANG Wen, CHU Wei, JIANG Chengfa ${ }^{*}$, WEN Jie, SUN Wenjing \\ Department of Chemical Engineer, Sichuan University, Chengdu 610065, Sichuan, China
}

\begin{abstract}
Ni} / \mathrm{MgO}, \mathrm{Ni} / \mathrm{CeO}_{2}-\mathrm{MgO}$, and $\mathrm{Ni} / \mathrm{CeO}_{2}$ catalysts were prepared by the citric acid combustion method. Their catalytic properties for the synthesis of multi-walled carbon nanotubes (MWCNTs) by chemical vapor deposition using $\mathrm{CH}_{4}$ as carbon source were evaluated. The catalysts were characterized with $\mathrm{N}_{2}$ adsorption, X-ray diffraction (XRD), $\mathrm{H}_{2}$ temperature-programmed reduction $\left(\mathrm{H}_{2}-\mathrm{TPR}\right)$, and X-ray photoelectron spectroscopy (XPS). The quality and structure of the CNTs were characterized by thermogravimetry (TG) and transmission electron microscopy (TEM). $\mathrm{H}_{2}$-TPR showed that $\mathrm{CeO}_{2}$ helped decrease the reduction temperature and increase the content of an easily reducible $\mathrm{Ni}$ species. XPS showed an energy shift of the Ni catalyst that was modified by $\mathrm{CeO}_{2}$. XRD showed that the reduced nickel maintained their small particle sizes in the $\mathrm{Ni} / \mathrm{CeO}_{2}-\mathrm{MgO}$ catalysts. These findings suggested that the addition of $\mathrm{CeO}_{2}$ changed the chemical environment of the nickel species, which resulted in a weaker interaction between the nickel and the support and increased the reducibility of the Ni species. Moreover, the reduced nickel was highly dispersed on the $\mathrm{CeO}_{2}-\mathrm{MgO}$ support. The change enhanced the catalytic activity for the growth of carbon nanotubes (CNTs). Characterization by TG and TEM showed that the quality of the CNTs grown on $\mathrm{Ni} / \mathrm{CeO}_{2}-\mathrm{MgO}_{\mathrm{O}}$ was better than those grown on $\mathrm{Ni} / \mathrm{MgO}$ catalyst.
\end{abstract}

Key words: nickel; magnesium oxide; cerium oxide; chemical vapor deposition method; carbon nanotubes; methane decomposition

Received 28 March 2011. Accepted 25 April 2011.

*Corresponding author. Tel: +86-28-85403836; Fax:+86-28-85461108; E-mail: jiangcf1@yahoo.com

This work was supported by the Fundamental Research Funds for the Central Universities (2010SCU22010) and the National Basic Research Program of China (973 Program, 2011CB201202).

English edition available online at Elsevier ScienceDirect (http://www.sciencedirect.com/science/journal/18722067). 
Carbon nanotubes (CNTs) have attracted significant research interest since their discovery by Ijiwa in 1991 [1]. CNTs have remarkable properties that make them suitable for a wide range of applications as chemical sensors [2], composite materials [3], electronic devices and so on. There are three techniques commonly used to grow CNTs, namely, arc discharge, laser ablation, and chemical vapor deposition (CVD). Among these, CVD is the most convenient way to grow all kinds of CNTs and the best choice to produce large amount of CNTs at relatively low cost and with mild growth conditions.

The carbon sources used include $\mathrm{CH}_{4}$ [4], $\mathrm{C}_{2} \mathrm{H}_{4}, \mathrm{C}_{2} \mathrm{H}_{2}$ [5], $\mathrm{CO}$ [6], ethanol [7] and so on, and is also one of main factors influencing the quality of the CNTs. Among the hydrocarbons, methane as the carbon source produce less impurity in the synthesized CNTs because it is difficult to decompose it in the gas phase and on the support.

In the CVD synthesis of CNTs, $\mathrm{Fe}, \mathrm{Co}, \mathrm{Ni}$, and their alloys [8] supported on oxides such as $\mathrm{Al}_{2} \mathrm{O}_{3}, \mathrm{SiO}_{2}$, and $\mathrm{MgO}$ [9] are used as the catalyst. $\mathrm{MgO}$ is considered a good support for the catalyst from the viewpoint of convenience and cost to purify the $\mathrm{CNT}$ product since $\mathrm{MgO}$ can be easily dissolved in dilute $\mathrm{HCl}$ solution.

A rare earth component $\mathrm{Ce}$ in a $\mathrm{Ni}$ or $\mathrm{Fe}$ catalyst played an important role in the synthesis of single-walled carbon nanotubes using arc discharge $[10,11]$ and the CVD method [12]. The addition of Ce prevented the sintering of Ni particles during reduction and maintained its distribution, which promoted the stability of the Ni catalyst [13]. Gueara et al. [14] found that Ni on a high surface area Ce-MCM-41 support showed excellent activity for methane decomposition.

In this work, $\mathrm{Ni} / \mathrm{CeO}_{2}-\mathrm{MgO}$ catalysts were prepared using the citric acid combustion method and used to synthesize CNTs by the CVD method using methane as the carbon source. The catalysts and CNTs were characterized by $\mathrm{H}_{2}$ temperature-programmed reduction $\left(\mathrm{H}_{2}-\mathrm{TPR}\right)$, X-ray diffraction (XRD), X-ray photoelectron spectroscopy (XPS), transmission electron microscopy (TEM), and thermogravimetry (TG). The results showed that the $\mathrm{Ni} / \mathrm{CeO}_{2}-\mathrm{MgO}$ catalyst had good catalytic activity for the decomposition of methane to synthesize CNTs.

\section{Experimental}

\subsection{Preparation of the catalysts}

The catalyst precursors for $\mathrm{Ni} / \mathrm{CeO}_{2}-\mathrm{MgO}$ were prepared by the citric acid combustion method. $\mathrm{Ni}\left(\mathrm{NO}_{3}\right)_{3} \cdot 6 \mathrm{H}_{2} \mathrm{O}$, $\mathrm{Ce}\left(\mathrm{NO}_{3}\right)_{3} \cdot 6 \mathrm{H}_{2} \mathrm{O}$, and $\mathrm{Mg}\left(\mathrm{NO}_{3}\right)_{2} \cdot 6 \mathrm{H}_{2} \mathrm{O}$ were mixed in a citric acid aqueous solution that was stirred and gelated at $70{ }^{\circ} \mathrm{C}$. After drying at $120^{\circ} \mathrm{C}$ overnight, the dried gel was calcined at $600{ }^{\circ} \mathrm{C}$ for $2 \mathrm{~h}$ in air to get the $\mathrm{Ni} / \mathrm{CeO}_{2}-\mathrm{MgO}$ catalyst.
The loading of $\mathrm{Ni}$ on the catalysts was kept at $50 \mathrm{wt} \%$. The contents of $\mathrm{CeO}_{2}$ were $0 \%, 20 \%, 40 \%$, and $50 \%$ for four different catalysts, and the remaining component was $\mathrm{MgO}$. For example, the $\mathrm{Ni} / 20 \mathrm{CeO}_{2}-\mathrm{MgO}$ catalyst had the weight ratio of $\mathrm{Ni}: \mathrm{CeO}_{2}: \mathrm{MgO}$ of 50:20:30. For comparison, $\mathrm{Ni} / \mathrm{MgO}$ and $\mathrm{Ni} / \mathrm{CeO}_{2}$ were also prepared by the same method.

\subsection{Characterization of catalyst and carbon nanotubes}

The specific surface areas of the catalysts were determined by $\mathrm{N}_{2}$ adsorption at $-196{ }^{\circ} \mathrm{C}$ on a Quantachrome Nova 1000 e apparatus. $\mathrm{H}_{2}$-TPR measurements were carried out at atmospheric pressure with a fixed bed reactor. The sample $(50 \mathrm{mg})$ was loaded and the reduction gas of $5 \% \mathrm{H}_{2}-95 \% \mathrm{~N}_{2}$ was introduced at a flow rate of $30 \mathrm{ml} / \mathrm{min}$. The temperature of the reactor was increased linearly at a rate of $5{ }^{\circ} \mathrm{C} / \mathrm{min}$ from 50 to $850{ }^{\circ} \mathrm{C}$ and kept for $30 \mathrm{~min}$ at $850{ }^{\circ} \mathrm{C}$. The effluent stream was analyzed for hydrogen by a thermal conductivity detector. Phase analysis was performed by XRD using a D/MAX-2500 (Rigaku Company) diffractometer with $\mathrm{Cu} K_{\alpha}(\lambda=0.154056 \mathrm{~nm})$ radiation. Data for the Bragg angle from $10^{\circ}$ to $90^{\circ}$ were collected. XPS experiments were performed on an XSAM800 spectrometer with an $\mathrm{Al}$ anode for $K_{\alpha}(h v=1486.6 \mathrm{eV})$ radiation. Charging effects were corrected by adjusting the binding energies using the $\mathrm{C} 1 s$ peak from carbon contamination at $284.6 \mathrm{eV}$. TG experiments were carried out under flowing air with a heating rate of $15^{\circ} \mathrm{C} / \mathrm{min}$. TEM images were taken with a Tecnai G2 F20 S-Twin microscope at an accelerating voltage of $200 \mathrm{kV}$.

\subsection{Synthesis of carbon nanotubes}

To grow CNTs, $0.03 \mathrm{~g}$ of catalyst powder was dispersed on each of three boats that were then placed in a horizontal quartz reactor (inner diameter $=3 \mathrm{~cm}$ ). First, the catalyst powder was reduced in situ in $\mathrm{H}_{2}$ at $550{ }^{\circ} \mathrm{C}$ for $1 \mathrm{~h}$. Subsequently, the sample was heated to $650{ }^{\circ} \mathrm{C}$ in flowing $\mathrm{N}_{2}$ and then the flow was switched to high purity methane (100 $\mathrm{ml} / \mathrm{min}$ ) for the cracking reaction of methane. After one hour's reaction, the CNTs grown were cooled to room temperature in a $\mathrm{N}_{2}$ atmosphere.

\section{Results and discussion}

\section{$2.1 \quad \mathrm{~N}_{2}$ adsorption results}

Table 1 presents the data for the specific surface areas of the catalysts. The specific surface areas of the catalysts in decreasing order were: $\mathrm{Ni} / \mathrm{MgO}>\mathrm{Ni} / 20 \mathrm{CeO}_{2}-\mathrm{MgO}>$ $\mathrm{Ni} / 40 \mathrm{CeO}_{2}-\mathrm{MgO}>\mathrm{Ni} / 50 \mathrm{CeO}_{2}$. The specific surface areas 
of the catalysts decreased with the increasing $\mathrm{CeO}_{2}$ content in them. Compared with the other catalysts, the specific surface area of $\mathrm{Ni} / 50 \mathrm{CeO}_{2}$ catalyst was decreased significantly due to the absence of $\mathrm{Mg}$. This would result in a low catalytic activity for the synthesis of CNTs using $\mathrm{Ni} / 50 \mathrm{CeO}_{2}$ as the catalyst.

Table 1 Specific surface areas of the different catalysts

\begin{tabular}{lcccc}
\hline Catalyst & \multicolumn{3}{c}{$\mathrm{Ni} / \mathrm{MgO}$} & $\mathrm{Ni} / 20 \mathrm{CeO}_{2}-\mathrm{MgO} \mathrm{Ni} / 40 \mathrm{CeO}_{2}-\mathrm{MgO} \mathrm{Ni} / 50 \mathrm{CeO}_{2}$ \\
\hline$A_{\mathrm{BET}} /\left(\mathrm{m}^{2} / \mathrm{g}\right)$ & 106.3 & 77.99 & 62.59 & 26.28 \\
\hline
\end{tabular}

\section{$2.2 \quad \mathrm{H}_{2}$-TPR characterization and analysis}

The redox properties of the catalysts were investigated with $\mathrm{H}_{2}$-TPR experiments. The profiles are shown in Fig. 1. The $\mathrm{H}_{2}$-TPR profile of $\mathrm{Ni} / \mathrm{MgO}$ showed a broad reduction band. The main reduction peak appearing at $770{ }^{\circ} \mathrm{C}$ was assigned to the reduction of $\mathrm{Ni}$ species interacting strongly with the support and the weak reduction peak at $500{ }^{\circ} \mathrm{C}$ was attributed to the reduction of $\mathrm{Ni}$ species which had a weak interaction with the support. Arena et al. [15] reported that the most reactive forms of $\mathrm{NiO}$ had undergone a progressive diffusion into the $\mathrm{MgO}$ lattice, and likely formed a $\mathrm{NiO} \cdot \mathrm{MgO}$ solid solution when the reduction temperature was higher than $600{ }^{\circ} \mathrm{C}$. So, most the nickel species were in the form of a solid solution in the $\mathrm{Ni} / \mathrm{MgO}$ catalyst, as the reduction temperature of these nickel species was higher than $600{ }^{\circ} \mathrm{C}$.

For catalysts with the composite support, the main reduction peak of the nickel species appeared at $525{ }^{\circ} \mathrm{C}$ for $\mathrm{Ni} / 20 \mathrm{CeO}_{2}-\mathrm{MgO}$ and at $460{ }^{\circ} \mathrm{C}$ for $\mathrm{Ni} / 40 \mathrm{CeO}_{2}-\mathrm{MgO}$. The reduction temperature of nickel decreased with increasing $\mathrm{CeO}_{2}$ content. There were two main reasons for the decrease of reduction temperature. First, the addition of $\mathrm{CeO}_{2}$ inhibited the forming of a $\mathrm{NiO} \cdot \mathrm{MgO}$ solid solution. When the reduction temperature was higher than $600{ }^{\circ} \mathrm{C}$, hydrogen consumption by the $\mathrm{Ni} / \mathrm{CeO}_{2}-\mathrm{MgO}$ catalysts decreased sig-

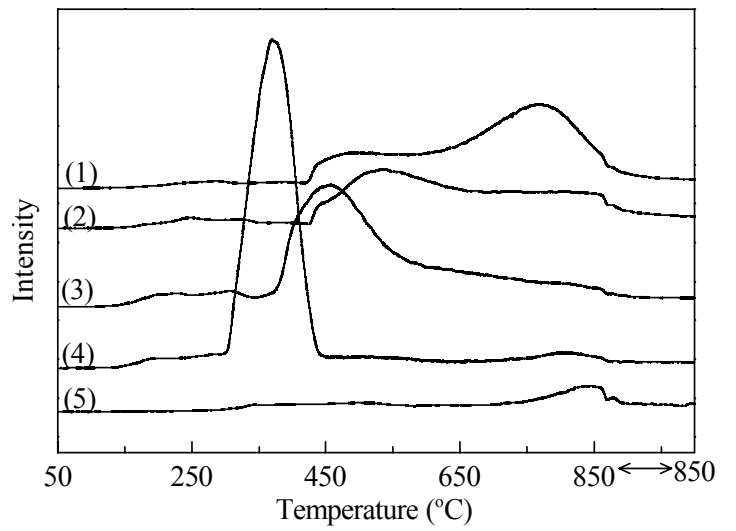

Fig. 1. $\mathrm{H}_{2}$-TPR profiles of the catalysts. (1) $\mathrm{Ni} / \mathrm{MgO} ;(2) \mathrm{Ni} / 20 \mathrm{CeO}_{2}$ $\mathrm{MgO}$; (3) $\mathrm{Ni} / 40 \mathrm{CeO}_{2}-\mathrm{MgO}$; (4) $\mathrm{Ni} / 50 \mathrm{CeO}_{2}$; (5) $\mathrm{CeO}_{2}$. nificantly relative to the $\mathrm{Ni} / \mathrm{MgO}$ catalyst. Second, a spillover effect of hydrogen on $\mathrm{CeO}_{2}$ also led to a decrease of the deoxidization temperature. The spillover effect of $\mathrm{CeO}_{2}$ can be explained by that $\mathrm{H}_{2}$ molecules adsorbed on the surface of $\mathrm{CeO}_{2}$ spillover onto the $\mathrm{NiO}$ phase, which promoted the reduction of $\mathrm{NiO}$ [16]. At the same time, the reduction of nickel was easy to sinter for the $\mathrm{Ni} / 50 \mathrm{CeO}_{2}$ catalyst, as much nickel species was reduced at a low temperature (380 $\left.{ }^{\circ} \mathrm{C}\right)$. This was proved by XRD result as follows. The decrease of reduction temperature and promotion of reduction degree of the nickel species provided more active sites for the growth of CNTs. A weak reduction peak appearing at $850{ }^{\circ} \mathrm{C}$ in the $\mathrm{H}_{2}$-TPR of $\mathrm{CeO}_{2}$ can be attributed to the reduction of $\mathrm{Ce}^{4+}$ to $\mathrm{Ce}^{3+}$. Similar reduction peaks were observed for the other catalyst samples.

\subsection{XPS characterization and analysis}

To further study the effects of cerium in these Ni-based catalysts, the $\mathrm{Ni} / \mathrm{MgO}, \mathrm{Ni} / 20 \mathrm{CeO}_{2}-\mathrm{MgO}, \mathrm{Ni} / 40 \mathrm{CeO}_{2}-\mathrm{MgO}$, and $\mathrm{Ni} / 50 \mathrm{CeO}_{2}$ samples were characterized by XPS. The Ni $2 p_{3 / 2}$ spectra and the corresponding Ni $2 p_{3 / 2}$ binding energy values of these samples are shown in Fig. 2. A typical Ni $2 p_{3 / 2}$ XPS spectrum of the $\mathrm{Ni} / \mathrm{MgO}$ sample showed peaks at 855.01 and $861.22 \mathrm{eV}$. The peak at $861.22 \mathrm{eV}$ was ascribed to a satellite peak of $855.01 \mathrm{eV}$. This catalyst had a higher $\mathrm{Ni} 2 p_{3 / 2}$ binding energy relative to $\mathrm{NiO}(854.5 \mathrm{eV})$ [17], which indicated that electron transfer took place from $\mathrm{Ni}$ to $\mathrm{Mg}$. When $\mathrm{Ce}$ was added into the $\mathrm{Ni} / \mathrm{MgO}$ sample, the $\mathrm{Ni}$ $2 p_{3 / 2}$ peak binding energy shifted from 855.01 to 854.73 and $854.67 \mathrm{eV}$ for $\mathrm{Ni} / 20 \mathrm{CeO}_{2}-\mathrm{MgO}$ and $\mathrm{Ni} / 40 \mathrm{CeO}_{2}-\mathrm{MgO}$, re-

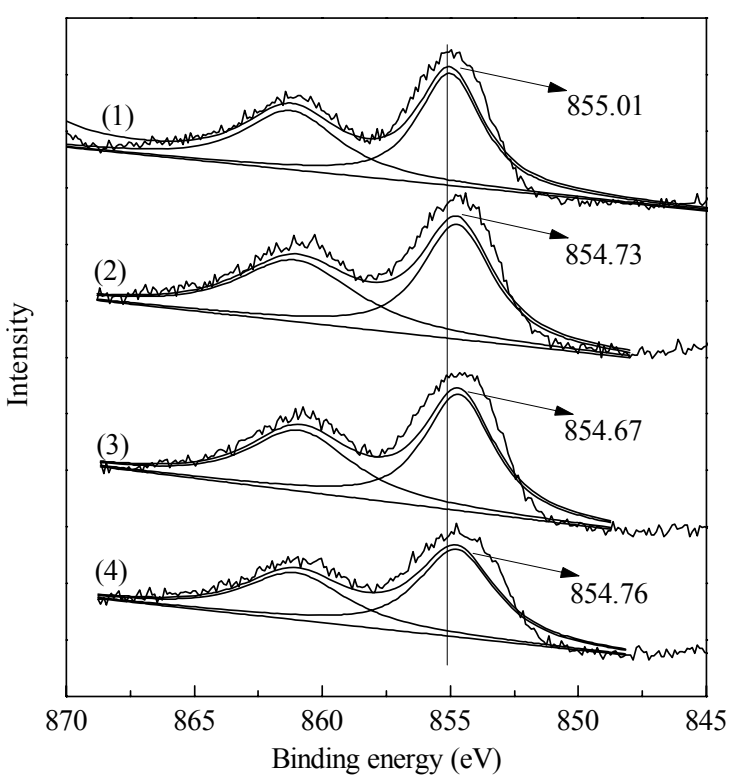

Fig. 2. Ni $2 p_{3 / 2}$ XPS spectra of various samples. (1) $\mathrm{Ni} / \mathrm{MgO}$; (2) $\mathrm{Ni} / 20 \mathrm{CeO}_{2}-\mathrm{MgO}$; (3) Ni/40CeO $-\mathrm{MgO}$; (4) $\mathrm{Ni} / 50 \mathrm{CeO}_{2}$. 
spectively. The significant differences in the Ni $2 p_{3 / 2}$ energies between the $\mathrm{Ni} / \mathrm{MgO}$ and $\mathrm{Ni} / \mathrm{CeO}_{2}-\mathrm{MgO}$ samples suggested that the chemical environment or structure surrounding the $\mathrm{Ni}$ ions were changed by the Ce element. The strong electron-withdrawing property of $\mathrm{Mg}$ made interaction strong between Ni species and support resulting in difficult reduction $\mathrm{Ni}$ species for the $\mathrm{Ni} / \mathrm{MgO}$ catalyst [18]. The $\mathrm{Ni}$ in $\mathrm{Ni} / \mathrm{CeO}_{2}-\mathrm{MgO}$ was electron-rich compared with the $\mathrm{Ni}$ in the $\mathrm{Ni} / \mathrm{MgO}$ sample. This result implied that the interaction between the nickel species and support was weakened in cerium oxide promoted $\mathrm{Ni} / \mathrm{MgO}$.

\subsection{XRD characterization and analysis}

Figure 3 shows the powder XRD patterns of the $\mathrm{Ni} / \mathrm{MgO}$, $\mathrm{Ni} / \mathrm{CeO}_{2}-\mathrm{MgO}$, and $\mathrm{Ni} / \mathrm{CeO}_{2}$ catalysts. These patterns have the same prominent reflections that can be assigned to $\mathrm{NiO}$, a solid solution $\mathrm{NiO} \cdot \mathrm{MgO}$ and $\mathrm{MgO}$ or a mixture of the three phases in unknown concentrations [19]. It is well known that the crystal type of $\mathrm{MgO}$ and $\mathrm{NiO}$ is cubic $\mathrm{NaCl}$. Moreover, $\mathrm{Ni}^{2+}(0.07 \mathrm{~nm})$ and $\mathrm{Mg}^{2+}(0.065 \mathrm{~nm})$ have similar ionic radii [18]. Therefore, oxide solid solutions of $\mathrm{NiO} \cdot \mathrm{MgO}$ can be formed with any ratio of $\mathrm{MgO}$ to $\mathrm{NiO}$ without significant structural changes that can be detected by XRD. After addition the $\mathrm{CeO}_{2}$ into $\mathrm{Ni} / \mathrm{MgO}$, the only remarkable feature observed in the powder XRD patterns was a progressive broadening of the respective reflection and diffraction peak of $\mathrm{CeO}_{2}$, which became progressively narrower. This indicated $\mathrm{CeO}_{2}$ inhibited crystal formation in $\mathrm{Ni} / \mathrm{MgO}$. In the $\mathrm{Ni} / 50 \mathrm{CeO}_{2}$ catalyst, the diffraction peak of $\mathrm{NiO}$ became narrower than for the $\mathrm{MgO}$ free sample.

To understand the nature of the nickel formed after the reduction of the catalysts, $\mathrm{Ni} / 20 \mathrm{CeO}_{2}-\mathrm{MgO}, \mathrm{Ni} / 40 \mathrm{CeO}_{2}$ $\mathrm{MgO}$, and $\mathrm{Ni} / 50 \mathrm{CeO}_{2}$ were reduced at $550{ }^{\circ} \mathrm{C}$. Subse-

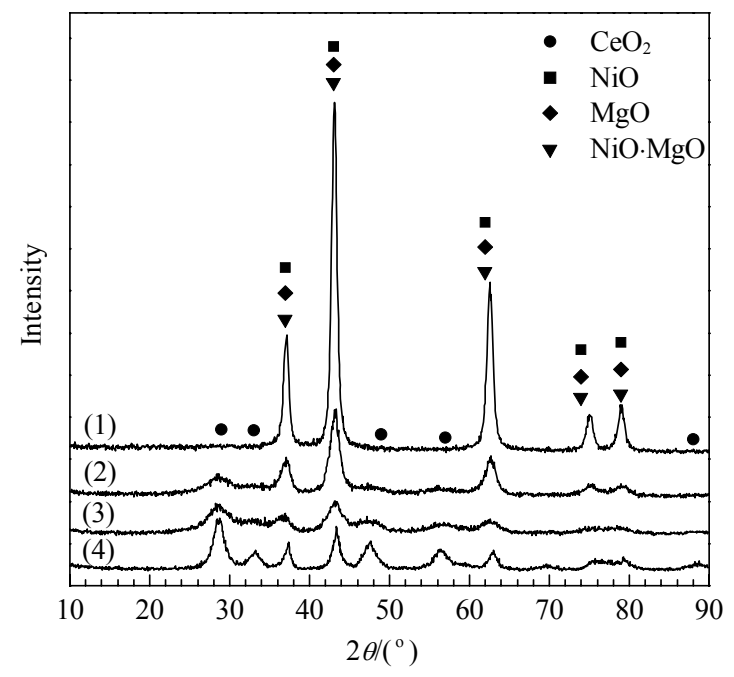

Fig. 3. Powder XRD patterns of the fresh catalysts. (1) $\mathrm{Ni} / \mathrm{MgO}$; (2) $\mathrm{Ni} / 20 \mathrm{CeO}_{2}-\mathrm{MgO}$; (3) Ni/40CeO $-\mathrm{MgO}$; (4) Ni/50CeO 2 . quently, XRD data (Fig. 3) were collected from the reduced catalysts. Figure 4 shows the XRD patterns of these samples. The XRD data showed peaks due to the nickel, $\mathrm{MgO}$, and $\mathrm{CeO}_{2}$ phases. The three intense XRD peaks of $2 \theta=$ $44.5^{\circ}, 51.8^{\circ}$, and $76.5^{\circ}$ corresponded to the diffraction peaks of $\mathrm{Ni}$. The intensities of the nickel peaks were not evidently different for $\mathrm{Ni} / 20 \mathrm{CeO}_{2}-\mathrm{MgO}$ and $\mathrm{Ni} / 40 \mathrm{CeO}_{2}$ $\mathrm{MgO}$, but the diffraction peak of nickel became sharp with $\mathrm{Ni} / 50 \mathrm{CeO}_{2}$. The particle sizes of nickel were $9.2,8.9$, and $13.2 \mathrm{~nm}$ for $\mathrm{Ni} / 20 \mathrm{CeO}_{2}-\mathrm{MgO}, \mathrm{Ni} / 40 \mathrm{CeO}_{2}$, and $\mathrm{Ni} / 50 \mathrm{CeO}_{2}$, respectively, which were estimated from the $\mathrm{X}$-ray line broadening of the nickel peak at $51.8^{\circ}$. From the XRD results, the particle sizes of reduced nickel were maintained at around $9 \mathrm{~nm}$. There was no sintering of the $\mathrm{Ni} / \mathrm{CeO}_{2}-\mathrm{MgO}$ catalysts, which implied reduced nickel was highly dispersed on the support. However reduced nickel was sintered in $\mathrm{Ni} / 50 \mathrm{CeO}_{2}$, resulting in the forming of large particles of $\mathrm{Ni}$ due to the high reducibility and the low reduction temperature of the active phase shown by the $\mathrm{H}_{2}$-TPR results.

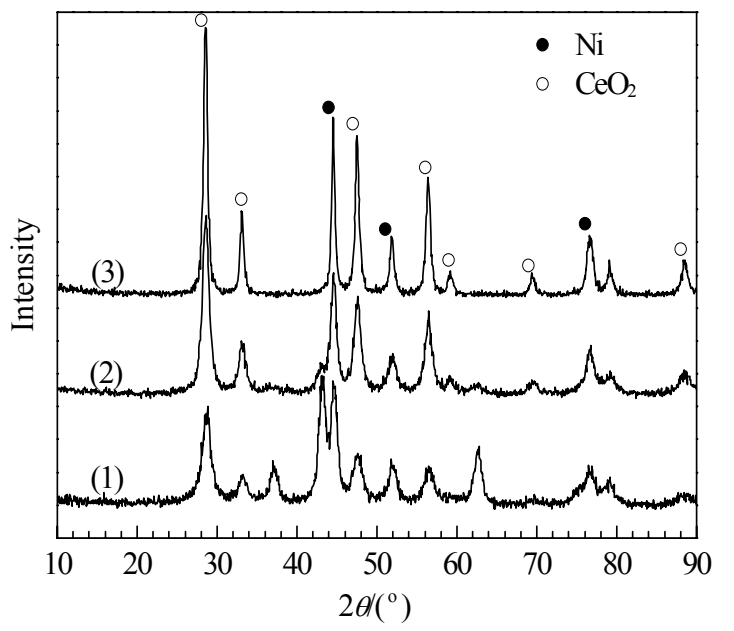

Fig. 4. Powder XRD patterns of the catalysts after reduction at $550{ }^{\circ} \mathrm{C}$ for 1 h. (1) $\mathrm{Ni} / 20 \mathrm{CeO}_{2}-\mathrm{MgO}$; (2) $\mathrm{Ni} / 40 \mathrm{CeO}_{2}-\mathrm{MgO}$; (3) $\mathrm{Ni} / 50 \mathrm{CeO}_{2}$.

\subsection{Catalytic properties for the growth of carbon nanotubes}

Figure 5 illustrates the yield of carbon nanotubes from the different catalysts. The addition of $\mathrm{CeO}_{2}$ significantly affected the catalytic activities of the $\mathrm{Ni} / \mathrm{MgO}$ catalysts. The CNT yields from $\mathrm{Ni} / \mathrm{MgO}, \mathrm{Ni} / 20 \mathrm{CeO}_{2}-\mathrm{MgO}, \mathrm{Ni} / 40 \mathrm{CeO}_{2}$ $\mathrm{MgO}$, and $\mathrm{Ni} / 50 \mathrm{CeO}_{2}$ were $0.41,3.61,7.53$, and $1.77 \mathrm{~g} / \mathrm{g}$, respectively. The result showed that the addition $\mathrm{CeO}_{2}$ into the $\mathrm{Ni} / \mathrm{MgO}$ catalyst gave a high catalytic activity for the growth of CNTs. It should be noted that the catalytic activity of $\mathrm{Ni} / 50 \mathrm{CeO}_{2}$ was significantly lower due to the low surface area and formation of large particles of nickel in the reduction process, which were shown by the BET and XRD analysis. 


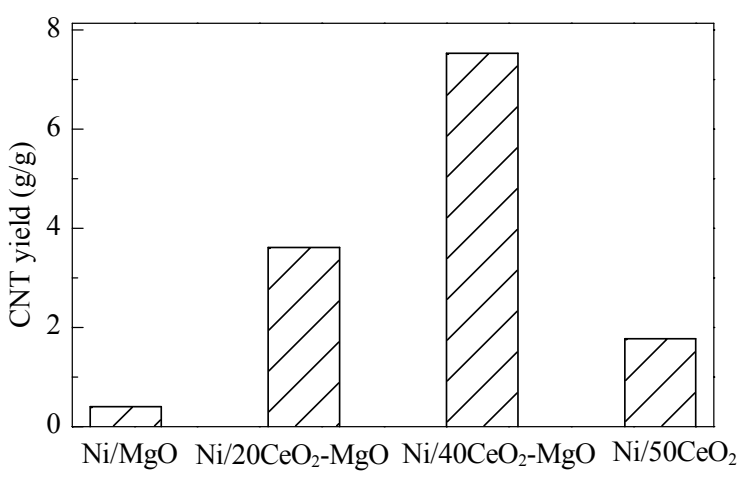

Fig. 5. Yield of CNTs with different catalysts at the synthesis temperature of $650{ }^{\circ} \mathrm{C}$ for $1 \mathrm{~h}$.

\subsection{TEM characterization and analysis}

The structure and morphology of the CNTs were observed using TEM images. Figure 6 shows the microstructure of the CNTs obtained from the $\mathrm{Ni} / \mathrm{MgO}$ and $\mathrm{Ni} / 40 \mathrm{CeO}_{2}-\mathrm{MgO}$ catalysts. As shown in Fig. 6(a), a lot of bead-like carbon deposits and twisted CNTs were formed, while the black catalyst particles were encapsulated by graphitic carbon that greatly inhibited the contact of catalyst and $\mathrm{CH}_{4}$. This also provided more evidence to explain the low activity of the $\mathrm{Ni} / \mathrm{MgO}$ catalyst. Figure 6(b) showed TEM images of the CNTs grown on the $\mathrm{Ni} / 40 \mathrm{CeO}_{2}-\mathrm{MgO}$ catalyst. A very high density of carbon nanotubes was observed. These possessed a well-crystallized multi-walled carbon nanotubes (MWCNTs) structure with almost no amorphous carbon and catalyst particles on their surface. Some CNTs of large diameters can be found in Fig. 6(b). The diameter of the carbon nanotubes greatly depends on the size of metal particles: larger Ni particles lead to CNTs with larger diameters. Some nanoparticles that had agglomerated in the reduction process would be responsible for this. Cui el al. [20] found that the growth of CNTs had lengthening and thickening stages. The CNTs were thickened substantially and the catalysts deactivated in the thickening stage. In the lengthening stage, the catalysts preserved their activity. The CNTs grown on the $\mathrm{Ni}$ / $20 \mathrm{CeO}_{2}-\mathrm{MgO}$ catalyst were longer and thinner than those

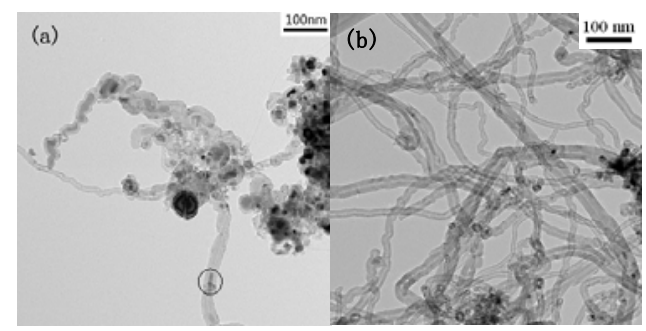

Fig. 6. TEM images of $\mathrm{CNTs}$ grown on $\mathrm{Ni} / \mathrm{MgO}$ (a) and $\mathrm{Ni} / 40 \mathrm{CeO}_{2}-\mathrm{MgO}$ (b). grown on the $\mathrm{Ni} / \mathrm{MgO}$ catalyst. This implied the composite supports catalyst gave better catalytic activity. TEM analysis also showed that spherical catalyst particles became elongated after the synthesis of CNTs (circled in Fig. 6(a)). This elongation of the nanoparticles may be due to the strong interaction between the CNTs and the catalyst. Similar changes to the particles were found by Rümmeli et al. [21].

\subsection{TG characterization and analysis}

Thermogravimetry analysis is an important analytical technique to show the quality of CNTs. It is used to quantitatively measure thermal stability, purity, and homogeneity [22]. Thermal stability is dependent upon a number of factors, e.g., defect density [23]. Three weight losses are recorded when the samples were heated in air. Those losses were attributed to the removal of amorphous carbon $\left(300-350{ }^{\circ} \mathrm{C}\right)$, CNTs $\left(400-650{ }^{\circ} \mathrm{C}\right)$ [23], and massive graphite carbon $\left(>700{ }^{\circ} \mathrm{C}\right)[24]$ at the different temperatures. Figure 7 illustrated the TG and DTG curves of the CNTs grown on the $\mathrm{Ni} / \mathrm{MgO}$ and $\mathrm{Ni} / 40 \mathrm{CeO}_{2}-\mathrm{MgO}$ catalysts. The TG results showed that the main weight losses were in the range of $380-600$ and $470-680{ }^{\circ} \mathrm{C}$ for the CNTs grown on the $\mathrm{Ni} / \mathrm{MgO}$ and $\mathrm{Ni} / 40 \mathrm{CeO}_{2}-\mathrm{MgO}$ catalysts, respectively. As shown in Fig. 7(a), the weight loss was about $3 \mathrm{wt} \%$ before $350{ }^{\circ} \mathrm{C}$ from the sample grown on $\mathrm{Ni} / \mathrm{MgO}$, which indicated some impurity carbon existed. Moreover, Fig. 7 showed that the weight loss curve of the CNTs grown on $\mathrm{Ni} / 40 \mathrm{CeO}_{2}-\mathrm{MgO}$ shifted to a higher temperature (from 509.9 to $626.8^{\circ} \mathrm{C}$ ) as compared with those grown on the $\mathrm{Ni} / \mathrm{MgO}$ catalyst, and a narrower temperature range was observed. The weight loss of the CNTs grown on the $\mathrm{Ni} / \mathrm{MgO}$ Catalyst was lower because the $\mathrm{Ni} / \mathrm{MgO}$ catalyst

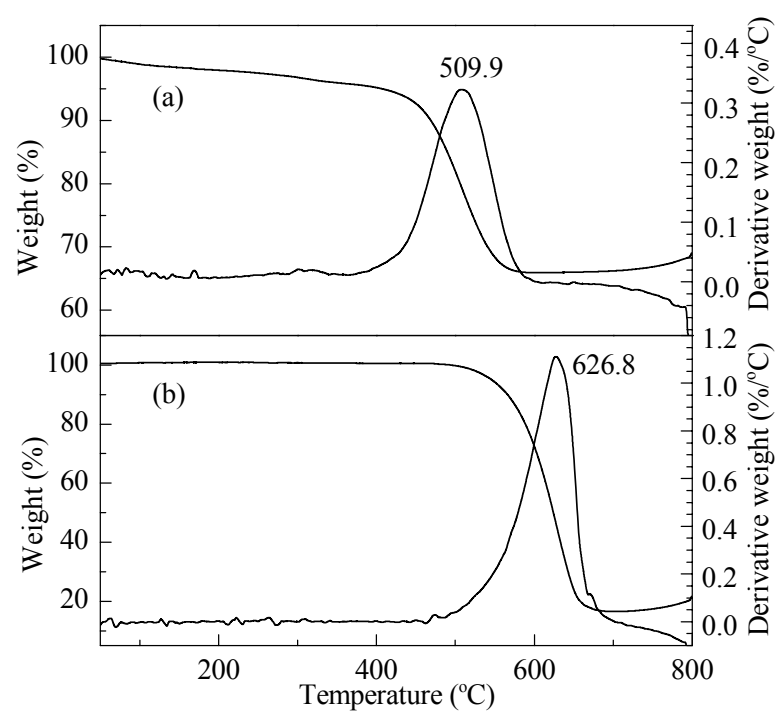

Fig. 7. TG and DTG curves of the as-prepared materials. (a) $\mathrm{Ni} / \mathrm{MgO}$; (b) $\mathrm{Ni} / 40 \mathrm{CeO}_{2}-\mathrm{MgO}$. 
deactivated easily, which increased the residual catalyst content [23]. The presence of numerous defects along the twisted walls also probably lowered the relative thermal stability of the CNTs on $\mathrm{Ni} / \mathrm{MgO}$ as these defects promoted oxidative combustion by providing edges and dangling bonds [8]. The oxidation temperature of the CNTs grown on the $\mathrm{Ni} / 40 \mathrm{CeO}_{2}-\mathrm{MgO}$ catalyst was associated with pure, less defective, and highly crystallized CNTs. The TG results further indicated that pure and well-crystallized CNTs were grown on the $\mathrm{Ni} / 40 \mathrm{CeO}_{2}-\mathrm{MgO}$ catalyst.

\section{Conclusions}

The addition of $\mathrm{CeO}_{2}$ to a $\mathrm{Ni} / \mathrm{MgO}$ catalyst caused more facile reducibility of the $\mathrm{Ni}$ species because the formation of a hardly reducible solid solution was inhibited. The reduced nickel retained a small nanoparticle size. XPS demonstrated that the Ce species affected the chemical environment of the $\mathrm{Ni}$ species. As a result, the $\mathrm{Ni} / \mathrm{CeO}_{2}-\mathrm{MgO}$ catalysts exhibited higher activities for the growth of CNTs. TEM and TG analyses showed that the $\mathrm{Ni} / \mathrm{MgO}$ catalyst was much covered by graphitic carbon that inhibited interaction with the carbon source gas and consequently gave a lower activity for carbon nanotube growth. In contrast, the CNT yield obtained from the $\mathrm{Ni} / 40 \mathrm{CeO}_{2}-\mathrm{MgO}$ catalyst was promoted and the CNTs obtained were pure with a well-crystallized structure.

\section{Acknowledgements}

The authors would like to thank Dr. Liu Ming and the TEM Group of Analytical Testing Center of Sichuan University.

\section{References}

1 Iijima S. Nature, 1991, 354: 56

2 Robinson J A, Snow E S, Bădescu Ş C, Reinecke T L, Perkins F K. Nano Lett, 2006, 6: 1747

3 MacDonald R A, Laurenzi B F, Viswanathan G, Ajayan P M,
Stegemann J P. J Biomed Mater Res A, 2005, 74A: 489

4 Zarabadi-Poor P, Badiei A, Yousefi A A, Fahlman B D, Abbasi A. Catal Today, 2010, 150: 100

5 Magrez A, Seo J W, Miko C, Hernadi K, Forro L. J Phys Chem B, 2005, 109: 10087

6 Mudimela P R, Nasibulin A G, Jiang H, Susi T, Chassaing D, Kauppinen E I. J Phys Chem C, 2009, 113: 2212

7 Liu J, Shao M, Chen X, Yu W, Liu X, Qian Y. J Am Chem Soc, 2003, 125: 8088

8 Maccallini E, Tsoufis T, Policicchio A, La Rosa S, Caruso T, Chiarello G, Colavita E, Formoso V, Gournis D, Agostino R G. Carbon, 2010, 48: 3434

9 Wen Q, Qian W, Wei F, Liu Y, Ning G, Zhang Q. Chem Mater, 2007, 19: 1226

10 Yao M, Liu B, Zou Y, Wang L, Cui T, Zou G, Li J, Sundqvist B. J Phys Chem B, 2006, 110: 15284

11 Liu B, Wågberg T, Olsson E, Yang R, Li H, Zhang S, Yang H, Zou G, Sundqvist B. Chem Phys Lett, 2000, 320: 365

12 El-Hendawy A-N A, Andrews R J, Alexander A J. Appl Surf Sci, 2009, 255: 7446

13 Zapata B, Valenzuela M A, Palacios J, Torres-Garcia E. Int J Hydrogen Energy, 2010, 35: 12091

14 Guevara J C, Wang J A, Chen L F, Valenzuela M A, Salas P, García-Ruiz A, Toledo J A, Cortes-Jácome M A, AngelesChavez C, Novaro O. Int J Hydrogen Energy, 2010, 35: 3509

15 Arena F, Licciardello A, Parmaliana A. Catal Lett, 1990, 6: 139

16 Li Y X, Guo Y H, Xue B. Fuel Process Technol, 2009, 90: 652

17 Kim K S, Winograd N. Surf Sci, 1974, 43: 625

18 Shi Q, Liu C, Chen W. J Rare Earth, 2009, 27: 948

19 Moliner R, Echegoyen Y, Suelves I, Lázaro M J, Palacios J M. Int J Hydrogen Energy, 2008, 33: 1719

20 Cui X W, Wei W F, Chen W X. Carbon, 2010, 48: 2782

21 Rümmeli M H, Schäffel F, Kramberger C, Gemming T, Bachmatiuk A, Kalenczuk R J, Rellinghaus B, Büchner B, Pichler T. J Am Chem Soc, 2007, 129: 15772

22 See C H, Harris A T. Ind Eng Chem Res, 2007, 46: 997

23 Porwal D, Mukhopadhyay K, Ram K, Mathur G N. Thermochim Acta, 2007, 463: 53

24 Loebick C Z, Derrouiche S, Marinkovic N, Wang C, Hennrich F, Kappes M M, Haller G L, Pfefferle L D. J Phys Chem C, 2009, 113: 21611 